\title{
First Language Use in Teaching a Foreign Language: Theoretical Perspectives and Empirical Findings
}

\author{
Seyyed Ali Ostovar-Namaghi, Shabnam Norouzi \\ University of Shahrood, Shahrood, Iran
}

\begin{abstract}
Although theoretical perspectives and empirical findings support the facilitative role of first language use in teaching a foreign or second language, in some contexts practitioners are reluctant to make use of this resource and those who use it feel guilty. This shows that language teaching follows social norms and expectations rather than principles of language teaching and learning. To demystify the role of mother tongue in language education, this study aimed at: reviewing the theoretical perspectives and empirical finings related to first language use; drawing implications for practitioners and other interested stakeholders. The review clearly shows that, among other things, teachers can use the mother tongue judiciously and reasonably to: arouse a sense of security in learners; build background prior to reading, listening, speaking, and writing tasks and activities; maximize intake by using L1 (first language) to make the input comprehensible; avoid giving learners the feeling of identity-threatened by the total rejection of their mother tongue; and help students with comprehension problems when L2 (second language) fails or is not effective.
\end{abstract}

Keywords: first language use, foreign language instruction

\section{Introduction}

The discrepancy between theory and practice motivated the researchers to undertake this study. Although there is lots of theoretical perspectives and empirical findings that support the constructive role of first language use in teaching a foreign language, a vast majority of our colleagues in private language schools of Iran are reluctant to use learners' mother tongue in foreign language education, and those who are forced to use it not only feel guilty but they are also censured by supervisors. Since these practitioners have no solid academic background in teaching English as a foreign language (TEFL), they are not aware of the theories and empirical findings which support first language use in foreign language instruction. As such, their negative attitude is deeply rooted in their lack of knowledge rather than their experience. We, the researchers, are sure that a great many of these practitioners will change their attitude if they are cognizant with the theoretical perspectives and empirical findings which clearly show that avoiding first language use at all costs deprives language learners from a very precious resource.

\section{Theoretical Perspectives}

Throughout the history of language teaching, there has been a heated debate between scholars and 
practitioners who follow an "intra-lingual strategy", i.e., a monolingual approach that rejects first language use, or a "cross-lingual strategy", which allows a judicious use of learners' first language or mother tongue (Stern, 1992). Following formalism, in the 18th century the use of $\mathrm{L} 1$ in teaching a foreign language was very common and it was most evident in Grammar Translation Method (Howatt, 1984). However, with the advent of activism in the 19th century, there was a shift away from written form to spoken form (Howatt, 1984) and the Berlitz Method marked the shift away from the cross-lingual strategy towards the intra-lingual strategy, which according to Howatt (1984) has three main features: (1) FL (foreign language) teaching should be done exclusively in the FL; (2) Translation between the mother tongue and foreign language should be avoided; and (3) In bilingual programs, the two languages should be kept separate. This tradition was so strong that it has overshadowed language teaching practices to date.

During the method era, it was Berlitz Method and the extreme version of the Direct Method that dogmatically and explicitly rejected first language use in second language instruction. Following behaviorism and structural linguistics, however, the Audio-lingual Method rejected L1 use on a scientific ground. That is, they believed that L1 should be avoided to minimize negative transfer. Other methods including Suggetopedia, Silent Way, Community Language Learning, and Communicative Language Teaching left some room for L1 use to clarify the meaning of dialogues, to give instructions when necessary, to establish a secure learning environment, and to help the flow of communicative activities and tasks respectively (Richards \& Rodgers, 2000).

When one goes beyond the realm of methods, again the history of language teaching is characterized by arguments pro and con first language use. While not explicitly rejecting the role of L1, some scholars advocate an intra-lingual strategy since they believe: (1) It is in line with the naturalistic principle, i.e., people can learn a second language in the same way as their first language (Cook, 2001); (2) Any reduction of the L2 would then be seen as a wasted opportunity for valuable comprehensible input (Krashen, 1981); (3) It helps learners internalize grammar and get used to thinking in English through exposure (Sharma, 2006); (4) It helps learners produce comprehensible output (Swain, 1985); (5) In EFL contexts, classroom is the only chance for students to use the target language in the classroom (McDonald, 1993); (6) That language is best learned when the language is used for real, meaningful communication (Canale, 1983; Nunan, 1987); and (7) That negotiation of meaning between learners, and between teachers and learners, is also seen as key to the second language acquisition process (Skehan, 2001).

Delving into the history of language teaching, Harbord (1992) contends that the "strategy of mother tongue avoidance" in ELT (English Language Teaching) can be explained by the emergence of two major trends: (1) the growth of ELT as a casual career for young travelers visiting Europe, which necessitated the use of English only in the classroom; and (2) the development of a "British-based teacher training movement", which aimed at providing guidance to English teachers working with multilingual classes (p. 350). Rejecting these historical trends and the theoretical perspectives preceding them, Auerbach (1993) said that "evidence from research and practice is presented which suggest that the rationale used to justify English only in the classroom is neither conclusive nor pedagogically sound" (p. 5).

On the other side of the continuum, according to Macaro (2005), there is the "Maximal position". The fans of this position believe that use of the mother tongue can sometimes be useful if it is used in due time. Along the same lines, Nation (1978) believes that excluding the mother tongue from the instruction environment of the classroom could be the same as avoidance of using objects and pictures in the second language classroom. 
Also, in support of L1 use, Finocchiaro and Boumfit (1983) believed that sensible use of L1 is acceptable where possible.

Following Krashen (1981), language learners develop their competence if teachers expose them to lots of comprehensible input. If the input is not comprehensible enough, acquisition will not be complete. To do so, the mother tongue can be a helpful tool. For instance, if the text is too difficult for the students to comprehend or if its comprehension depends on having some background knowledge, the teacher can build this background using students' mother tongue. Similarly, Atkinson (1987) recommends using the L1 equivalents for eliciting language and comprehension checking by both teacher and student in the form of "How do you say _ in English?" Thus first language use can facilitate the flow of communication in the target language.

Some scholars reject the monolingual approach to language instruction on many other grounds. Hopkins (1988) believed that if the learner of another language is inspired to omit his own language from the L2 learning process and completely ignores it, they might feel identity-threatened. In addition, Skinner (1985) rejected the exclusive use of the target language on practical grounds by expressing the difficulties in connection with the use of the L2 exclusively in the classroom. To support this idea, Stern (1992) questioned the traditional belief of L2 only classrooms by arguing that learner's L1 could have a reasonable place in FL classroom. Moreover, Auerbach (1993) believed that using students' L1 arouses a sense of security in them since without their mother tongue they are not able express themselves and their experiences in their mother tongue, especially at the beginning states of language development.

Along the same line, Schweers (1999) emphasized the importance of judicious and selective use of L1 in L2 classroom to help facilitate the learning process. To support this notion, Eldridge (1996) believed there is no empirical evidence to support the notion that restricting mother tongue use would necessarily improve learner efficiency. Interestingly, Atkinson (1987) also added that "total prohibition of the students' L1 is now unfashionable" (p. 241).

Far from being an obstacle, for some scholars learners' first language is a precious resource. For instance Stern (1992) considered the judicious use of L1 as a resource that turns input to intake. Similarly, based on his experience, Cook (2001) believed that optimal first language use is conducive to having more authentic L2 users. He further believed that finding cognates and similarities between the languages develops an "interlinked L1 and L2 knowledge in the students' minds". By the same token, Cook (2001) and Tang (2002) believed that occasional use of L1 by both students and teachers increases both comprehension and L2 learning since L1 plays a supportive role in the classroom. Thus it can be concluded that teachers should use L1 tactfully and judiciously in the classroom.

Despite its facilitating roles, the mother tongue in the EFL classroom has been a skeleton in the cupboard (Pradromou, 2001). Teachers do not have a positive feeling towards using it and mostly feel ashamed and considered English only classrooms as more efficient. However, in response, Gabrielatos (2001) believed that L1 has been more "a bone of connection" than "a skeleton in the cupboard". He stated that "the skeleton has been there all the time; we just have not wanted to talk about it, because perhaps we have not had the psycholinguistic or pedagogic framework in which to do so" (p. 8). He thought that a bilingual teacher could amend L2 learning by the use of the mother tongue: "if the L1 facilitates learning, then we use it" (p. 8).

Taking the facilitating function of L1 in teaching L2, in a clean and brief categorization Wharton (2007) explains three major ways in which the students' L1 can be used in the language classroom: (1) providing L1 equivalents of English words and expressions; (2) using L1 to focus on language in use; and (3) using L1 for 
classroom interaction. Reiterating these functions, Nation (2003) added another useful function of L1 by considering it as a productive instrument for communicating meaning. In addition to these functions, optimal L1 use in teaching a foreign or second language can be justified since: (1) Initiating with the learners' mother tongue grants the learners a sense of security and accredits students' lived experience (Auerbach, 1993); and (2) L1 use grants students "cognitive support" that enables them to explore language and produce work of higher standard by playing the role of a bridge for students to analyze the language and try more than the time they use foreign language only (Storch \& Wigglesworth, 2003).

Despite the pedagogical functions of L1, some practitioners dogmatically reject L1 in language teaching. A situation of this kind was reported by Nunan (1999) describing a situation where an EFL teacher in China imposed fines on his students in situations they spoke Cantonese in the classroom. The result was not appealing and the learners became totally silent. Neither did they use the mother tongue, nor did they use English. The teacher got his wish of no Cantonese, but ironically he did not get any English from his students either (p. 158).

Putting their prejudices aside, practitioners should let L1 fulfill its facilitating functions in language classes since: (1) When learners are allowed to use their mother tongue, they can express themselves more effectively (Wharton, 2007); and (2) From a humanistic perspective, it is highly unlikely that a teacher would refuse to answer a question like "How can I say 'Ça m'est égal'?" (Harbord, 1992); it is the "preferred learning strategies" of most of language learners in language classrooms around the world (Atkinson, 1987, p. 242); it is a time saving device (Wharton, 2007; Atkinson, 1987; Tudor, 1987; Copland \& Neokleous, 2010).

\section{Empirical Findings}

Different empirical studies have been done to show the noteworthy role of the mother tongue in foreign language teaching (Nation, 2003). As an early study in this field, Duff and Polio (1990) observed 13 L2 classes and found that teachers often applied the mother tongue to explain grammar, manage the class and maintain the discipline, translate vocabulary items. and help students with comprehension problems and their students were pleased with the use of L1. In a similar study, Schweers (1999) found that 88.7 percent of the learners felt that Spanish as their L1 were a good way to explain difficult concepts. Also 67 percent stated that their mother tongue helped them to feel "less lost". They believed that the use of Spanish let them be more comfortable, check their comprehension, and be able to understand new vocabulary items.

Along the same lines, Januleviciene and Kavaliauskiene (2002) did a research on ESP and found that most of the teachers and students are in favor of using the native language in the classroom. $86 \%$ of the teachers believed that L1 use will definitely help L2 learning. In another study, Copland and Neokleous (2010) did a study on L1 use. They observed four classrooms and also interviewed the teachers in Greece. These teachers expressed that they used the mother tongue for the purpose of saving time, providing a more successful classroom experience, and reducing the amount of stress their students felt. Contrary to the previous studies, Nazari (2008) found that most of Persian language learners of all proficiency levels did not think that L1 use could be helpful or effective strategy for L2 learning.

To discover the purpose of L1 use in an L2 classroom, De La Campa and Nassaji (2009) observed two teachers at the university level and found that teachers used L1 for two distinct functions: (1) to make the classroom environment enjoyable; and (2) to give activity instructions. Moreover these teachers believed in L1 use as an effective strategy in L2 teaching. Moreover, Lourie (2010) found that teachers used L1 to translate texts, to raise learners' meta-linguistic awareness, and to facilitate communicative activates. Moreover, they 
found that teachers used L1 less at lower levels and preferred to use L1 more for higher levels.

Rezvani and Eslami (2011) did an explanatory study of code-switching (CS) between English and Farsi by four Iranian English foreign language (EFL) teachers and found that: (1) CS could be a good device for bilingual teachers when learners and teachers share the same ethnic and cultural background; and (2) L1 use in the classroom contributes to better learners' comprehension and better teacher-student relationship. In a survey at a Japanese university, where L1 use was officially banned, McMillan and Rivers (2011) discovered that use of L1 in FL classrooms promoted cognition, communication, and social functions in language classrooms. In this context L1 use was officially banned.

In another research by Tsafi (2012), distributed a questionnaire among 112 elementary and secondary English teachers in Hebrew-speaking schools in Israel and found teachers generally had a positive attitude towards the use of the mother, but they also had a feeling of guilt while using L1 since it was not accepted by authorities. In line with this study, Naci Kayaoglu (2012) launched a study with 44 teachers of English at Karadeniz Technical and demonstrated that: (1) Most teachers' attitudes towards using Turkish in teaching English were positive and the practical and pedagogical effects of its use could not be ignored; and (2) L1 can be used in teaching grammar but it should be avoided in teaching speaking and listening.

While in other EFL contexts teachers and students' had a positive attitude towards using mother tongue and recognized its potential in developing learners' target language competence, teachers and learners in Iranian private language schools have a negative attitude and as such they are reluctant to use mother tongue in teaching English. For instance, Mahmudi and Yazdiamirkhiz (2011) studied the quantity of L1 use in two pre-university classes in Ahvaz, Iran and found that students were opposed to overusing L1 in L2 classrooms and did not like L1 to be the dominant language of the classrooms. Teachers and also students from all proficiency levels generally had L2 as their priority to be used in L2 classrooms. In a similar study, which aimed to discover Iranian students' and teachers' attitudes towards using the mother tongue in the general English classrooms, Hashemi and Khalili (2013) found a conflict of interest between teachers and students: While learners emphasized the feeling of comfort that L1 grants in L2 classrooms, teachers were eager to use L2 more than L1. In a similar study in the same context, Yaqubi and Pourmoid (2013) tried to discover Iranian teachers' and parents' perspectives on the use of L1 in private English language schools in and found that: (1) Parents did not have a positive attitude towards L1 use in language institutes and since these schools survived on the budget provided by them and they should follow their preferences; and (2) Less experienced teachers followed parents' expectations since they were more vulnerable while experienced teachers tried to stick to their own reasons and ideas.

A critical review of the foregoing empirical findings clearly shows that while in almost all other contexts teachers and learners have a positive attitude towards L1 use, in private language schools in Iran, teachers and learners are not willing to use L1. As Yaqubi and Pourmoid (2013) clearly showed that teachers' attitude reflect parents' negative attitude towards L1 use. Moreover, although there are both qualitative and quantitative studies investigating the use of mother tongue in teaching a second or foreign language, they are all limited in that:

(1) Quantitative studies were of survey type and no study investigated the comparative effect of a cross-lingual and intra-lingual strategy under experimental conditions;

(2) Qualitative studies described stakeholders' attitude towards mother tongue use in second language without explaining the social and cultural forces that shaped these attitude; hence, none of them had explanatory adequacy and remained at the level of description. 


\section{Implications for Practice}

Both the theoretical perspectives and the empirical findings related to L1 use in language education clearly show that despite the prejudiced rejection of L1 use in some contexts, it can be a precious resource which fulfills a multitude of functions in helping teachers develop language learners' target language competence. Taking the theories and empirical findings into account, it is suggested that teachers use learners' mother tongue judiciously and optimally to:

(1) Arouse a sense of security in learners since without their mother tongue they are not able to express themselves completely, especially in lower levels of proficiency;

(2) Build background in reading, listening, speaking, and writing tasks and activities;

(3) Maximize intake by using L1 to make the input comprehensible;

(4) Avoid giving learners the feeling of identity-threatened by the total rejection of their mother tongue;

(5) Avoid any possible incomprehension or misunderstanding;

(6) Show the similarities of L1 and L2 subsystems;

(7) Raise students' metacognitive awareness;

(8) Acknowledge the fact that willy-nilly learners in their mind use and refer to their mother tongue while communicating, especially at the beginning levels;

(9) Save time when using the target language leads to misconception, misunderstanding and task difficulty;

(10) Help students with comprehension problems when L2 fails or is not effective;

(11) Grant students "cognitive support" that enables them to explore language and produce work of higher standard;

(12) Let students express themselves in their mother tongue when they feel they can't express themselves in English;

(13) Acknowledge individual differences and learners preferred learning strategy , e.g., the learner may ask the teacher to explain a grammatical structure in mother tongue while the teacher's preferred strategy is giving examples;

Moreover, the study has precious implications for schoolmasters and supervisors. Taking the facilitating function of Judicious L1 use, it is essential that schoolmasters:

(1) Not let parents' perspectives, which are devoid of any pedagogical insight, affect their decisions and consequently teaching and learning activities;

(2) Leave their prejudice behind and not force teachers deprive students from L1 when it facilitates instruction;

(3) Follow theoretical perspectives and empirical findings related to L1 use rather than their instinct and unjustified social norms;

(4) Respect post-method pedagogy which shifted away from "either/or" towards "both/and" in describing teaching options.

\section{Conclusion}

When Berlitz Method and the early version of Direct Method were formulated, language teaching was in its infancy. Although they prescribed that practitioners should avoid first language use at any costs, they 
presented no theories or empirical findings in support of their claim; hence, their prescriptions reflected the subjective judgment of the designers rather than their theoretical sensitivity. Today, however, language teaching has come of age and, as the review clearly shows, practitioners have a myriad of theories and empirical findings to rely on for the judicious use of learners' mother tongue in foreign language education. Moreover, while in the methods era language teaching was formulated in terms of binary opposites, i.e., inductive or deductive, cross-lingual or intra-lingual, communicative drills or mechanical drills, medium-oriented or message-oriented, learning or acquisition, in post-method era, language teaching strategies are presented in terms of complimentary pairs, i.e., both inductive and deductive, both communicative drills and mechanical drills, both medium-oriented and message oriented. Following the same logic, the post-method pedagogy liberates us from methods prescriptions and lets us use both the intra-lingual and cross-lingual strategies whenever they help foreign language instruction.

\section{References}

Afzal, S. (2013). Using of the first language in English classroom as a way of scaffolding for both the students and teachers to learn and teach English. International Research Journal of Applied and Basic Sciences, 4(7), 1846-1854.

Atkinson, D. (1987). The mother tongue in the classroom: A neglected resource? ETL Journal, 41(4), 241-247.

Atkinson, D. (1993). Teaching monolingual classes. Harlow: Longman Group UK Limited.

Auerbach, E. (1993). Reexamining English only in the ESL classroom. TESOL Quarterly, 27, 9-32.

Brown, H. D. (2000). Principles of language learning and teaching (4th ed.). New York: Addison Wesley Longman.

Canale, M. (1983). From communicative competence to communicative language pedagogy. In J. C. Richards and R. W. Schmidt (Eds.), Language and communication. London: Longman.

Cianflone, E. (2009). L1 use in English courses at university level. ESP World, 8(22), 1-6.

Cook, V. (2001). Using the first language in the classroom. The Canadian Modern Language Review, 57(3), 402-423.

Copland, F., \& Neokleous, G. (2011). L1 to teach L2: Complexities and contradictions. ELT Journal, 65(3), $270-280$.

De la Campa, J. C., \& Nassaji, H. (2009). The amount, purpose, and reasons for using L1 in L2 classrooms. Foreign Language Annals, 42, 742-759.

Duff, P., \& Polio, C. (1990). How much foreign language is there in the foreign language classroom? Mod Lang Journal, 74, 154-166.

Dujmovic, M. (2007). The use of Croatian in the EFL classroom. Metodicki Obzori, 2(1), 91-100.

Edstrom, A. (2006). L1 use in the L2 classroom: One teacher's self-evaluation. Canadian Modern Language Review, 2, $275-292$.

Eldridge, J. (1996). Code-switching in a Turkish secondary school. ELT Journal, 50(4), 303-311.

Ellis, R. (1984). Second language development. Oxford: Pergamon.

Finnochiaro, M., \& Brumfit, C. J. (1983). The functional-notional approach: From theory to practice. New York: Oxford University Press.

Gabrielatos, C. (2001). L1 use in ELT: Not a skeleton, but a bone of contention. Retrieved from $\mathrm{http}: / /$ tesolgreece.com/nl/70/7001.html

Harbord, J. (1992). The use of the mother tongue in the classroom. ELT Journal, 46(4), 350-355.

Hashemi, S. M., \& Khalilisabet, M. (2013). The Iranian EFL students' and teachers' perception of using Persian in general English classes. International Journal of Applied Linguistics \& English Literature, 2(2), 142-152.

Herdina, P., \& Jessner, U. (2002). A dynamic model of multilingualism: Perspectives of change in psycholinguistics. Clevedon, England: Multilingual Matters.

Hopkins, S. (1988). Use of mother tongue in teaching of English as a second language to adults. Language Issues, 2(2), 18-24.

Howatt, A. (1984). A history of English language teaching. Oxford: Oxford University Press.

Jan, C. W., Li, B. J., \& Lin, C. C. (2014). The use of the mother tongue in Chinese EFL classrooms. Journal of China University of Science and Technology, 58(1), 161-181.

Januleviciene, V., \& Kavaliauskiene, G. (2002). Promoting the fifth skill in teaching ESP. Retrieved from http://www.espworld.info/Articles_2/Promoting\%20the\%20Fifth\%20Skill\%20in\%20Teaching\%20ESP\% 20 
Jessner, U., \& Cenoz, J. (2000). Expanding the score: Sociolinguistic, psycholinguistic and education aspects of learning English as a third language in Europe. In J. Cenoz and U. Jessner (Eds.), English in Europe: The acquisition of a third language (pp. 248-260). Clevedon, England: Multilingual Matters.

Krashen, S. (1981). Second language acquisition and second language learning. Oxford: Pergamon.

Krashen, S. (1982). Principles and practice in second language acquisition. Oxford: Pergamon.

Kuhi, D., \& Abdolvasg, M. (2014). Azerbaijan Turkic speaking English language teachers' attitudes towards the use of their mother tongue in English classes. International Journal of Research Studies in Language Learning, 3, 58-72.

Lourie, I. (2010). English only? The linguistic choices of teachers of young EFL learners. International Journal of Bilingualism, 14, 351-367.

Macaro, E. (2005). Code-switching in the L2 classroom: A communication and learning strategy. In E. Llurda (Ed.), Non-native language teachers: Perceptions, challenges, and contributions to the profession (pp. 63-84). Boston, MA: Springer.

Mahmudi, L., \& Yazdiamirkhiz, Y. (2011). The use of Persian in the EFL classroom-The case of English teaching and learning at pre-university level in Iran. English Language Teaching, 4(1), 135-140.

McDonald, C. (1993). Using the target language. Cheltenham, UK: Mary Glasgow.

McMillan, B., \& Rivers, D. J. (2011). The practice of policy: Teacher attitudes toward "English-only". System, 39, 251-263.

Naci Kayaoglu, M. (2012). The use of mother tongue in foreign language teaching from teachers' practice and perspective. Pamukkale University Journal of Education, 1, 26-32.

Nation, I. S. P. (1978). Translation and the teaching of meaning: some techniques. ELT Journal, 32(3), 171-175.

Nation, P. (2003). The role of the first language in foreign language learning. Asian EFL Journal, 5(2), 1-18.

Nazary, M. (2008). The role of L1 in L2 acquisition: Attitudes of Iranian university students. Novitas Royal, 2, 138-153.

Nunan, D. (1987). Communicative language teaching: making it work. ELT Journal, 41(2), 136-145.

Nunan, D. (1999). Second language teaching \& learning. Boston: Heinle \& Heinle Publishers.

Rezvani, H., \& Eslami Rasekh, A. (2011). Code-switching in Iranian elementary EFL classrooms: An exploratory investigation, English Language Teaching, 4(1), 18-25.

Richards, J. C., \& Rodgers, T. (2000). Approached and methods in language teaching (2nd ed.). New York: Cambridge University Press.

Schweers, C. W. (1999). Using L1 in the L2 classroom. English Teaching Forum, 37(2), 6-13.

Sharma, K. (2006). Mother tongue use in English classroom. Journal of NELTA, 11(1-2), 80-87.

Skehan, P. (2001). Comprehension and production strategies in language learning. In C. N. Candlin and N. Mercer (Eds.), English language teaching in its social context (pp. 75-89). New York: Routledge.

Skinner, D. (1985). Access to meaning: The anatomy of the language/learning connection. J Multiling Multicult Dev, 6, 369-389.

Stern, H. H. (1992). Issues and options in language teaching. Oxford: Oxford University Press.

Storch, N., \& Wigglesworth, G. (2003). Is there a role for the use of L1 in an L2 setting? TESOL Quarterly, 37(4), 760-770.

Swain, M. (1985). Communicative competence: Some roles of comprehensible input and comprehensible output in its development. In S. Gass and C. Madden (Eds.), Input in second language acquisition (pp. 235-253). Rowley, MA: Newbury House.

Swan, M. (1985). A critical look at the communicative approach (2). Oxford Journals Humanities ELT Journal, 39(2), $76-87$.

Tang, J. (2002). Using L1 in the English classroom. English Teaching Forum, 40, 36-43.

Timor, T. (2012). Use of the mother tongue in teaching a foreign language. Language Education in Asia, 3, 7-14.

Tudor, I. (1987). Using translation in ESP. ELT Journal, 41(4), 268-273.

Turnbull, M. (2001). There is a role for the L1 in second and foreign language teaching, but... Canadian Modern Language Review, 57(4), 150-163.

Wharton, C. (2007), Informed use of the mother tongue in the English language classroom. Retrieved from http://www.birmingham.ac.uk/Documents/collegeartslaw/cels/ essays/secondlanguage/ wharton-p-grammar.pdf

Willis, J. (1991). Teaching English through English. Essex (England): Longman.

Yaqubi, B., \& Pouromid, S. (2013). First language use in English language institutes: Are teachers free to alternate between L1 and L2 as means of instruction? The Journal of Teaching Language Skills (JTLS), 4(4), 127-152. 